УДК 159.942.5:364-787.522

DOI https://doi.org/10.26661/2310-4368/2021-1-15

\title{
АДАПТАЦЙНІ ВЛАСТИВОСТІ У СКЛАДІ ЕМОЦІЙНО-ФУНКЦІОНАЛЬНОГО ПОТЕНЦІАЛУ ОСОБИСТОСТІ
}

\author{
Степаненко Л. В. \\ кандидат психологічних наук, дочент, \\ доичент кафедри психології \\ Донбаський державний педагогічний університет \\ вул. Генерала Батюка, 19, Слов'янськ, Донецька область, Украӥна \\ orcid.org/0000-0002-2891-9006 \\ lora.step.74@gmail.com
}

\begin{abstract}
Ключові слова: емочійна саморегуляція, копінг-стратегї, механізми психологічного захисту, емоичійні властивості, властивості емоиійного реагування.
\end{abstract}

У статтіпредставленотеоретичнийаналізпроблемиемоційно-функціонального потенціалу як частини більш загальної категорії потенціалу особистості. Проаналізовано структурні складники емоційно-функціонального потенціалу: емоційні властивості особистості, адаптивні властивості особистості, копінгстратегії та механізми психологічного захисту.

Виявлено кількісні та якісні характеристики зв'язків адаптаційних властивостей із особистісними емоційними властивостями та копінгзахисними механізмами у психологів. Визначено взаємозв'язок адаптивних властивостей iз характеристиками емоційного реагування (емоційна збудливість, інтенсивність емоцій, емоційна лабільність-ригідність, експресивність, емоційна стійкість-нестійкість, оптимізм-песимізм) і стійкими емоційними властивостями (тривожність, напруження, безпечність, сміливість у соціальних контактах, емоційна стійкість). Встановлено відсутність зв'язків показника стійкої емоційної властивості «емоційна чуйність» із показниками адаптаційного потенціалу.

3'ясовано, що адаптаційні можливості особистості значною мірою визначаються їі емоційними властивостями, які мають тісний зв'язок із копінгзахисними механізми. Визначено взаємозв'язки адаптивних властивостей із копінг-захисними механізмами особистості (конфронтація, самоконтроль, визнання відповідальності, втеча-уникнення, планомірне вирішення проблеми; витіснення, регресія, заміщення, проекція, гіперкомпенсація).

Доведено, що копінг-стратегії «пошук соціальної підтримки», «планування розв'язання проблем» мають зворотні зв'язки 3 показниками моральної нормативності та загальним показником адаптивності особистості; копінгстратегії «дистанціювання», «позитивна переоцінка» та захисні механізми особистості «заперечення», «компенсація», «раціоналізація» не показали взаємозв'язку з адаптивними властивостями психологів. Узагальнено, що успішність адаптаційного процесу у стресових ситуаціях визначається своєрідним репертуаром копінг-стратегій, захисних механізмів і компонентів адаптаційного потенціалу.

Отримані результати експериментального дослідження дали змогу отримати нові дані в розумінні роботи емоційно-функціонального потенціалу особистості, який базується на емоційних властивостях особистості у зв'язку 3 копінг-захисними механізмами. 


\title{
ADAPTIVE PROPERTIES IN THE COMPOSITION OF THE EMOTIONAL- FUNCTIONAL POTENTIAL OF THE PERSONALITY
}

\author{
Stepanenko L. V. \\ Candidate of Psychological Sciences, Associate Professor, \\ Associate Professor at the Department of Psychology \\ Donbas State Pedagogical University \\ Heneral Batiuk str., 19, Slovyansk, Donetsk region, Ukraine \\ orcid.org/0000-0002-2891-9006 \\ lora.step.74@gmail.com
}

Key words: emotional self-
regulation, coping-strategies,
mechanisms of psychological
protection, emotional properties,
properties of emotional reaction.

Постановка проблеми. До числа не досить осмислених психологічних понять, актуальних для нового витка розвитку психологічної науки, входить поняття потенціалу. Психологічні словники та підручники 3 психології не надають визначення терміну «потенціал», оскільки у психології фрагментарно відображаються тільки деякі аспекти цієї психологічної проблеми.
The article presents the theoretical analysis of the problem of the emotionalfunctional potential as part of a more general category of the potential of the personality. The structural components of the emotional-functional potential are analyzed: emotional personality traits, adaptive personality traits, coping strategies and mechanisms of psychological protection. Quantitative and qualitative characteristics of the connections of the adaptive properties with the personal emotional properties and coping-protective mechanisms in psychologists have been revealed.

The interrelation of adaptive properties with the characteristics of emotional response (emotional excitability, emotional intensity, emotional lability-rigidity, expressiveness, emotional stability-instability, optimism-pessimism) and stable emotional properties (anxiety, stress, security, courage in social contacts, emotional stability) is determined. There is no connection between the indicator of the stable emotional property "emotional sensitivity" and the indicators of adaptive potential. It is found that the adaptive capacities of the personality are largely determined by his/her emotional properties, which in turn are closely related to coping-protective mechanisms. The interrelations of the adaptive properties with coping-protective mechanisms of the personality (confrontation, self-control, recognition of responsibility, escape-avoidance, planned solution of the problem; displacement, regression, substitution, projection, hypercompensation) are determined.

It is found that the coping strategies "search for social support", "planning to solve problems" have feedback on the indicators of moral normalization and the general indicator of adaptability of the personality; the coping strategies of "distancing", "positive reassessment" and the personality defense mechanisms "denial", "compensation", "rationalization" did not show the interrelation with the adaptive properties of psychologists. It is proved that the success of the adaptive process in stressful situations is determined by a kind of repertoire of coping strategies, protective mechanisms, and components of adaptive potential.

The results of the experimental study have provided new data in understanding the work of the emotional-functional potential of the personality, which is based on the emotional properties of the personality in connection with copingprotective mechanisms.
Потенціал як універсальна загальнонаукова категорія означає сукупність наявних засобів, можливостей у конкретній області [1]. Найчастіше термін «потенціал» використовується не як специфічне наукове поняття, а як синонім терміну «ресурси» або «можливості» [2].

В.М. Марков, Ю.В. Синягін визначають потенціал людини як систему ресурсів, які поновлюються та виявляються в діяльності, спрямованій на 
отримання соціально значущих результатів. Науковці виділяють такі моменти: по-перше, потенціал людини є ресурсним показником, у зв'язку 3 цим повинен мати будь-який числовий показник; по-друге, цей ресурс не є назавжди даним, він повинен постійно оновлюватися протягом життя; по-третє, потенціал реалізується у взаєминах 3 оточенням; по-четверте, потенціалу людини притаманна системна якість [3]. С.В. Ситнік зауважує, що «потенціал» визначається науковцями як психологічний феномен, який інтегрально описує мотиви і здібності особистості [4].

Отже, у цьому аспекті потенціал людини розглядається як сили, можливості, ресурси, резерв у досягненні цілі, тобто людина, яка має потенціал, наділена силою, що здатна виявитися у визначених умовах. Психологічні ресурси людини допомагають їй подолати життєві труднощі, конфлікти, проблемні ситуації, кризи. Якщо можливості особистості виявляються в безпосередньо спостережуваній ситуації, то особистісний потенціал формується, накопичується, розвивається нерідко у прихованій від спостереження формі і тільки після цього виявляється в актуальній ситуації [5].

П.В. Лушин досліджує динаміку особистісного потенціалу в контексті проблеми особистісних змінювань і посттравматичного росту [6]. Таке тлумачення поняття потенціалу відносить його до категорії особистості, до можливостей і здібностей конкретної людини.

У контексті сучасних наукових досліджень психологів проблему особистості покладено в основу численних теоретико-методологічних пошуків. До поняття потенціалу відносять комплекс різних взаємопов'язаних психологічних якостей і характеристик особистості, які у сукупності входять до значення поняття особистісного потенціалу. «Особистісний потенціал» має широкий діапазон досліджень, які характеризуються різноплановістю і відсутністю концептуальних напрацювань.

Аналізуючи численні наукові теоретичні розробки, ми виділили кілька напрямів у дослідженні питання особистісного потенціалу, а саме: 1) характеристики феномену «особистісний потенціал» і його використання в діяльності; 2) загальна проблематика особистісного потенціалу у психології. В межах першого напряму дослідників цікавлять особливості особистісного потенціалу в контексті його реалізації у діяльності, професійній взаємодії, управлінській діяльності. Ці дослідження мають фрагментарний характер і стосуються певних аспектів цієї психологічної проблеми (Б.Г. Ананьєв, Г.О. Балл, Л.С. Виготський, В.В. Давидов, А.М. Матюшкін, В.М. Мясищев, Б.М. Теплов та інші).

Так, С.Д. Максименко визначає потенціал як можливість, яка, реалізуючись у діяльності, удо- сконалюється, залишаючись потенційною (ймовірнісною можливістю), тоді як діяльність відокремлена від потенціалу і $є$ засобом досягнення поставленої мети [7; 8]. У межах другого напряму на перший план висуваються проблеми сутності поняття особистісного потенціалу як психологічного феномену, його видів, специфіки, складників. Саме цей напрям у дослідженні питання особистісного потенціалу вважаємо найбільш значущим для вказаного дослідження.

Потенціал особистості розглядається як джерело розвитку людини, що забезпечує іiі успішність у процесі життєдіяльності (Я. Кальба, Д.О. Леонтьєв, С.Д. Максименко, І.П. Маноха, I.В. Мурашко, В.І. Подшивалкіна, М.А. Садова та інші). Науковці пов'язують потенціал особистості із певними процесами актуалізації, реалізації, розгортання, відтворення, прагненням вийти за межі своїх рамок, самовираження, самоствердження, самореалізації, інтеріоризації (Б.Г. Ананьєв, І.С. Кон, Д.О. Леонтьєв, В.М. Мясищев, С.Л. Рубінштейн, В.К. Сафонов, А. Маслоу, Г. Олпорт, К. Роджерс, В. Франкл, Е. Фром та інші) [9]. Так, Д.О. Леонтьєв наголошує, що особистісний потенціал $€$ інтегральною характеристикою рівня особистісної зрілості. Головним феноменом особистісної зрілості і формою вияву особистісного потенціалу є феномен самодетермінації особистості, тобто здійснення діяльності відносно вільно від заданих умов цієї діяльності [10].

Разом із тим, усі дослідження з проблеми особистісного потенціалу розглядають і інші види потенціалів, на яких базується особистісний потенціал: психофізіологічний (В.І. Медведєв, Г.М. Зараковський), професійний (І.П. Маноха), енергопотенціал (С.Д. Максименко), інтелектуальний (В.М. Дружинін, Т.В. Прохоренко), інноваційний (В.Е. Клочко, Є.В. Галажинський), самовизначення і самореалізації (Д.О. Леонтьєв), духовний (Д.В. Паригін, Е.О. Помиткін, В.Д. Шадріков), комунікативний, ціннісно-світоглядний, мотиваційний, творчий (І.В. Воронюк, В.О. Моляко, О.Л. Шульган), аксіологічний, адаптаційний потенціали (К.О. Абульханова-Славська, А.Г. Маклаков, С.Д. Максименко).

Зазначимо, що усі види потенціалів мають пряме відношення до особистісного потенціалу, але описують лише окремі його сторони. Неважко здогадатися, що поняття «потенціал» має структуру (як зовнішню, так і внутрішню). I дуже часто відсутність або неможливість визначення потенціалу говорить про невикористання усіх складників цього поняття. Одним зі складників такої системи як потенціал $є$ емоційні структурні компоненти.

До вивчення проблеми «емоційний потенціал» у психології не існує єдиного ставлення (погляду), а тим більше визначення цього поняття як психо- 
логічної категорії. Більшість дослідників не використовують це поняття взагалі чи використовують його більш широко в межах особистісного потенціалу (колективного потенціалу).

Проблема емоційного потенціалу у психології найбільш представлена через емоційні феномени колективу. Емоційний потенціал насамперед визначається особистісним потенціалом індивідів. Так, Н.В. Попова виокремлює емоційно-моральний потенціал як частковий компонент більш загальної категорії «потенціал особистості», який визначається задатками, здібностями, потребами, ціннісними установками, нахилами, неактуалізованими можливостями, творчими імпульсами, потребами в пізнанні себе і свого оточення.

Манфред Кетс де Вріс, професор INSEAD, найвідоміший дослідник лідерства, стверджує, що емоційний потенціал - це здатність розпізнавати, адаптуватися і управляти якомога ширшим спектром емоцій. Усе це дозволить систематизувати свій досвід і відкрити для себе практичність та ефективність емоцій як інструменту управління i ресурсу для збільшення продуктивності праці і підвищення власної ефективності і у бізнесі, і в особистих відносинах [11].

Отже, без розуміння поняття потенціалу в контексті психології особистості не можливо обгрунтувати ключове для нашого дослідження поняття «емоційного-функціонального потенціалу». Але саме поняття особистісного потенціалу теж вирізняється різноманіттям дефініцій, повною відсутністю концептуально-методологічних підходів, пояснюється різноманітністю парадигмальної прихильності авторів різних наукових традицій, що дозволяли б різнобічно дослідити цей феномен.

Емоційно-функціональний потенціал особистості ми розуміємо як один із видів особистісного потенціалу. Він визначається не лише сукупністю емоційних властивостей особистості, а як pecypc, який допомагає особистості подолати життєві труднощі, стресові ситуації, кризи. Емоційно-функціональний потенціал включає в себе особливу функціональну взаємодію емоційних властивостей у зв'язку із копінг-захисними механізмами як складниками емоційної саморегуляції та пов'язаними 3 певними процесами самореалізації, адаптації, самоактуалізації.

Мета статті - проаналізувати особливості взаємозв'язків адаптаційних та емоційних властивостей, копінг-стратегій, механізмів психологічного захисту психологів у стресових ситуаціях.

Виклад основного матеріалу дослідження. 3 метою аналізу проблеми адаптаційних властивостей у складі емоційно-функціонального потенціалу особистості (на прикладі психологів) ми провели дослідження. Участь у експерименталь- ному дослідженні взяли 86 психологів Донецької області віком від 25 до 50 років, які самі пережили стресові події та продовжують працювати із населенням у «сірих» зонах.

Для дослідження складників емоційної саморегуляції особистості було використано такі методи: 1) копінг-тест Р. Лазаруса в адаптації Т.Л. Крюкової та співавторів; 2) опитувальник Плутчика Келлермана Конте - Індекс життєвого стилю (LifeStyleIndex, LSI); 3) самооціночний тест «Характеристики емоційності» Є.П. Ільїна-шкала «емоційна збудливість», «інтенсивність емоцій», «тривалість емоцій»; 4) фрайбургський опитувальник - шкала «емоційна лабільність»; 5) опитувальник емпатії В.В. Бойко - шкала «емоційний канал емпатії»; 6) методика емоційно-енергетичних зарядів В.В. Бойко; 7) методика індекс життєвого задоволення в адаптації Н.В. Паніної шкала «загальний фон настрою» методики індекс життєвого задоволення в адаптації Н.В. Паніної; 8) 16-ти факторний особистісний опитувальник Р.Б. Кеттелла - блок емоційних властивостей. Для дослідження адаптаційних властивостей був використаний багатофакторний особистісний опитувальник «Адаптивність» А.Г. Маклакова в адаптації C.В. Чермяніна. За допомогою цього опитувальника можна оцінити адаптаційні властивості особистості та їх роль у складі емоційно-функціонального потенціалу.

Результати дослідження адаптаційних властивостей психологів показали, що показники комунікативних здібностей, моральної нормативності виражені на середньому рівні. Одночасно з цим показник нервово-психічної стійкості, загальний показник особистісного адаптивного потенціалу знаходиться в межах низького рівня.

Зазначимо, що успішність процесу адаптації визначається не абсолютною величиною адаптаційного потенціалу, а відносною. Відносність величини особистого адаптаційного потенціалу може розглядатися як механізм формування ресурсів, індивідуальний стиль їх витрачання, відновлення і взаємозбагачення, можливість компенсації ресурсів, яких не вистачає, гнучкості їхнього використання в межах деяких границь потенціалу. Через це навіть при низьких адаптаційних ресурсах окремо характер їх об'єднання у потенціал, за певних внутрішніх і зовнішніх умов, може призвести до високої ефективності адаптації [12].

Проаналізовано взаємозв'язки між показниками адаптивних властивостей і показниками емоційних властивостей як складників емоційної саморегуляції особистості. Встановлено прямі кореляційні зв'язки між адаптивною властивістю особистості «нервово-психічна стійкість» та емоційними властивостями особистості: «емоційна збудливість», «глибина переживання 
емоцій», «емоційна лабільність-ригідність», «емоційна чуйність», «експресивність», «емоційна стійкість», «оптимізм-песимізм»; зі стійкими емоційними властивостями «тривожність» $(\mathrm{r} \leq 0,343)$, «напруження» $(\mathrm{r} \leq 0,426)$ і зворотній зв'язок із показниками «сміливість у соціальних контактах» $(\mathrm{r} \leq-0,500)$, «емоційна стійкість» $(\mathrm{r} \leq-0,552)$.

Особливість зв'язків із характеристиками емоційного реагування та стійкими емоційними властивостями демонструє емоційну насиченість поведінкової регуляції. Виникає широкий спектр характеристик емоційного реагування від емоційного збудження, тривалості емоцій до емоційної чуйності, експресивності, оптимізму. Усі ці вияви фіксуються на фоні високої тривожності особистості, емоційної нестійкості, імпульсивності, зниженого настрою. Отже, емоційні властивості зумовлюють поведінку особистості та визначають особливості сприйняття стресової ситуації.

Прямі кореляційні зв’язки виявлено між адаптивною властивістю «комунікативний потенціал» та такими емоційними властивостями особистості: «емоційна збудливість», «глибина переживання емоцій», «емоційна лабільність-ригідність», «емоційна чуйність», «експресивність», «емоційна стійкість», «оптимізм-песимізм»; зі стійкими емоційними властивостями «тривожність» $(r \leq 0,310)$, «напруження» $(r \leq 0,314)$ та зворотній зв'язок із показниками «безпечність» $(\mathrm{r} \leq-0,470)$, «сміливість у соціальних контактах» $(\mathrm{r} \leq-0,715)$, «емоційна стійкість» $(\mathrm{r} \leq-0,452)$. Ці результати свідчать про те, що активація характеристик емоційного реагування, емоційна нестійкість, тривожність особистості призводять до драматизації стресової ситуації і утруднення спілкування з оточуючими, взаємодії, побудови комунікативних контактів.

Встановлено прямі кореляційні зв'язки між адаптивною властивістю «моральна нормативність» та емоційними властивостями особистості: «емоційна збудливість», «емоційна лабільність-ригідність», «експресивність», «емоційна стійкість», крім показників «глибина переживання емоцій», «емоційна чуйність», «оптимізм-песимізм»; зі стійкими емоційними властивостями зворотній зв'язок із показниками «сміливість у соціальних контактах» $(\mathrm{r} \leq-0,330)$, «емоційна стійкість» $(\mathrm{r} \leq-0,394)$. Отже, показник моральної нормативності емоційно насичений, але немає широкого спектру емоційних перепадів, про що свідчить відсутність таких емоційних характеристик як інтенсивність емоцій, емоційна чуйність, оптимізм.

Існують прямі кореляційні зв'язки між адаптивною властивістю особистості «особистісний адаптаційний потенціал» та емоційними властивостями особистості: «емоційна збудливість», «глибина переживання емоцій», «емоційна лабільність-ригідність», «емоційна чуйність», «експресивність», «емоційна стійкість», «оптимізм-песимізм»; зі стійкими емоційними властивостями «тривожність» $(r \leq 0,335)$, «напруження» $(r \leq 0,395)$ та зворотній зв'язок із показниками «сміливість у соціальних контактах» $(\mathrm{r} \leq-0,568)$, «емоційна стійкість» $(\mathrm{r} \leq-0,556)$. Отримані дані демонструють актуалізацію усіх емоційних властивостей психологів під час стресової ситуації. Виявлено широкий спектр характеристик емоційного реагування, тривожність, відсутність емоційної стійкості, що призводять до зниження загальної тенденції процесу адаптації.

Показник стійкої емоційної властивості «емоційна чуйність» не утворює зв'язків із показниками адаптаційного потенціалу. Очевидно, що адаптаційні можливості особистості значною мірою визначаються іiі емоційними властивостями, які мають тісний зв'язок із копінг-захисними механізми.

Встановлені взаємозв'язки між показниками адаптивної властивості «нервово-психічна стійкість» і показниками копінг-захисних механізмів особистості як складників емоційної саморегуляції: «конфронтація» $(\mathrm{r} \leq 0,455)$, «самоконтроль» $(\mathrm{r} \leq 0,318)$, «визнання відповідальності» $(\mathrm{r} \leq 0,421)$, «втеча-уникнення» $(\mathrm{r} \leq 0,479)$; «регресія» $(\mathrm{r} \leq 0,743)$, «заміщення» $(\mathrm{r} \leq 0,693)$, «проекція» $(\mathrm{r} \leq 0,449)$, «гіперкомпенсація» $(\mathrm{r} \leq 0,370)$. Це означає, що у психологів при середньому рівні поведінкової регуляції порушене реальне сприймання дійсності, спостерігаються імпульсивність у поведінці, існують труднощі при плануванні дій. Вони прагнуть приховати від оточуючих свої переживання, які викликані стресовою ситуацією. Визнають свою відповідальність, але відчувають, що використання стереотипних форм поведінки не працюють у нових умовах стресової ситуації. Спроби подолання негативних переживань відбуваються шляхом розвитку протилежних прагнень, ухилення від проблем, перенесенням назовні.

Існують прямі кореляційні зв'язки між адаптивною властивістю особистості «комунікативний потенціал» і копінг-захисними механізмами психологів: «конфронтація» $(\mathrm{r} \leq 0,486)$, «визнання відповідальності» $(\mathrm{r} \leq 0,401)$, «втеча-уникнення» $(\mathrm{r} \leq 0,467)$, «регресія» $(\mathrm{r} \leq 0,683)$, «заміщення» $(\mathrm{r} \leq 0,543)$, «проекція» $(\mathrm{r} \leq 0,339)$. Отже, психологи завдяки своїм комунікативним здібностям виявляють енергійність, демонструють вміння відстоювати свої інтереси у стресових ситуаціях, розуміють залежність між особистими діями та їх наслідками. Вони 
здатні установлювати контакти 3 оточуючими, не виявляють конфліктності, не мають труднощів у спілкуванні $з$ іншими. Природно, що психологи у стресових ситуаціях відчувають накопичення труднощів, не можуть стримати своїх бажань, висловлюють те, що думають. 3 метою зниження емоційної напруги вони часто переносять на інших та приписують їм негативні, неприємні характеристики.

Встановлено зворотні кореляційні зв’язки між адаптивною властивістю особистості «моральна нормативність» і копінг-стратегіями психологів: «пошук соціальної підтримки» $(\mathrm{r} \leq-0,342)$, «планомірне вирішення проблеми» $(\mathrm{r} \leq-0,362)$ та прямі зв'язки із захисними механізмами: «витіснення» $(\mathrm{r} \leq 0,426)$, «регресія» $(\mathrm{r} \leq 0,512)$, «заміщення» $(\mathrm{r} \leq 0,418)$. Ці результати свідчать про те, що психологи сприймають та оцінюють себе відповідно до своєї соціальної ролі, дотримуються загальноприйнятих норм. Але у стресовій ситуації не завжди здатні цілеспрямовано оцінити ситуацію, використати попередній досвід, знайти можливі варіанти розв'язання проблеми, звернутися за підтримкою до соціального оточення. Завдяки механізмам психологічного захисту свою імпульсивність та спонтанність дій, неприємні спогади, що викликають тривожність, психологи блокують, витісняють зі свідомості.

Досліджено прямі кореляційні зв'язки між інтегральним показником «особистісний адаптаційний потенціал» і копінг-механізмами: «конфронтація» $(\mathrm{r} \leq 0,462)$, «визнання відповідальності» $(\mathrm{r} \leq 0,408)$, «втеча-уникнення» $(\mathrm{r} \leq 0,471)$, зворотній зв'язок із показником «планомірне вирішення проблеми» $(\mathrm{r} \leq-0,306)$; із захисними механізмами «регресія» $(\mathrm{r} \leq 0,761)$, «заміщення» $(\mathrm{r} \leq 0,679)$, «проекція» $(\mathrm{r} \leq 0,432)$, «гіперкомпенсація» $(\mathrm{r} \leq 0,344)$. Отже, під час адаптації психологи протидіють стресовій ситуації, розуміють залежність між особистісними діями та їх наслідками. Водночас вони прагнуть відійти від відповідальності при вирішенні проблем, тому не мають цілеспрямованих дій та адекватної оцінки стресової ситуації. Дія захисних механізмів витіснення, регресія, заміщення спрямована на зниження емоційного напруження.

Копінг-стратегії «дистанціювання», «позитивна переоцінка» та захисні механізми особистості «заперечення», «компенсація», «раціоналізація» не показали взаємозв'язку з адаптивними властивостями психологів.

Показники усіх рівнів адаптаційних властивостей утворюють прямі зв'язки із показниками захисних механізмів «регресія», «заміщення». Механізми витіснення, проекції, гіперкомпенсації мають вибіркові прямі зв’язки із показниками адаптивних властивостей.
Таким чином, показники адаптаційних властивостей як «нервово-психічна стійкість», «комунікативні властивості», інтегральний показник особистісного адаптаційного потенціалу утворюють прямі зв'язки із копінг-стратегіями «конфронтація», «визнання відповідальності», «втеча-уникнення». Зворотній зв'язок спостерігається в інтегрального показника адаптаційного потенціалу із показником копінг-стратегії «планування вирішення проблеми», а також у показника «моральна нормативність» iз показниками копінг-стратегій «планування вирішення проблеми» та «пошук соціальної підтримки». Отже, успішність адаптаційного процесу у стресових ситуаціях визначається своєрідним репертуаром копінг-стратегій, захисних механізмів і компонентів адаптаційного потенціалу. Зазначимо також, що навіть у межах низького рівня вираження адаптаційного потенціалу ефективність адаптації досягається за рахунок копінг-захисних механізмів як складника емоційної саморегуляції.

Висновки. Отримані взаємозв'язки показників адаптаційних властивостей із показниками емоційних властивостей, а також показниками копінг-захисних механізмів дозволяють визначити змістовні характеристики адаптаційного рівня емоційно-функціонального потенціалу особистості. Цей рівень складають характеристики емоційного реагування (емоційна збудливість, інтенсивність емоцій, емоційна лабільність-ригідність, експресивність, емоційна стійкість-нестійкість, оптимізм-песимізм) та стійкі емоційні властивості (тривожність, напруження, безпечність, сміливість у соціальних контактах, емоційна стійкість).

Також адаптаційний рівень емоційно-функціонального потенціалу містить компоненти особистісного адаптаційного потенціалу, копінг-стратегії «конфронтація», «визнання відповідальності», «втеча-уникнення», «планування вирішення проблеми», «планування вирішення проблеми», «пошук соціальної підтримки», показники механізмів захисту «регресія», «заміщення», витіснення, проекції, гіперкомпенсації.

Ефективність емоційно-функціонального потенціалу особистості при порушеннях балансу в системі «особистість - соціальне середовище» визначається гнучкістю системи адаптивних механізмів, можливостями формування ресурсів, індивідуального стилю їх витрачання і компенсації.

Перспективними напрямами дослідження вважаємо вивчення змістовних характеристик рівня самоактуалізації емоційно-функціонального потенціалу особистості. 


\section{ЛІТЕРАТУРА}

1. Василенко П.М., Васильченко В.С., Галицький В.М. Словник-довідник соціального працівника : навч. посіб. К. : ІПКДСЗУ, 2007. 322 с.

2. Дикая Л.Г. Личностный потенциал и эмоциональное выгорание педагога. Человек. Сообщество. Управление. 2012. № 3. С. 75-88.

3. Марков В.М. Механизмы реализации потенциала в контексте акмеологии развития. Мир психологии. 2007. № 2(50). С. 61-73.

4. Ситнік С.В. Особистісний потенціал як умова професійної взаємодії. Вісник ОНУ імені І.І. Мечникова. Психологія. 2012. Т. 17. Вип. 8(20). С. 168-175.

5. Мурашко I.В. Розкриття поняття «особистісний потенціал» та його психологічної структури. Актуальні проблеми психології. Психологічна теорія і технологія навчання. К. : Смульсон, 2010. Т. 8. Вип. 7. С. 196-205.

6. Лушин П.В. Хаос и неопределенность: от страдания - к росту и развитию. К. : Астрая, 2017.

7. Максименко С.Д. Генеза здійснення особистості. К. : Видавництво ТОВ «КММ», 2006. 240 с.

8. Максименко С.Д. Загальна психологія. Видання 3-є, перероблене та доповнене : навчальний посібник. К. : Центр учбової літератури, 2008. 272 с.

9. Попова Н.В. Эмоционально-нравственный потенциал менеджера как ключевая характеристика профессиональной деятельности менеджера. Научно-теоретический журнал. Научное обеспечение системы повышения квалификации кадров. 2009. Вып. 2. С. 77-83.

10. Леонтьев Д.А. Личностный потенциал: структура и диагностика. М. : Смысл, 2011.

11. Манфред К.В. Мистика лидерства. Развитие эмоционального интеллекта. Пер. с англ. М. : Альпина Бизнес Букс, 2004. 311 с.

12. Богомолов. А.М. Личностный адаптационный потенциал в контексте системного анализа. Психологическая наука и образование. 2008. № 1. С. 67-73.

\section{REFERENCES}

1. Vasylenko P.M., Vasylchenko V.S., Halytskyi V.M. (2007) Slovnyk-dovidnyk sotsialnoho pratsivnyka : navch. posib. [Dictionary-reference book of a social worker : textbook. way.] K. : IPKDSZU. 322 s. [in Ukrainian].

2. Dikaya L.G. (2012) Lichnostnyj potencial i emocional'noe vygoranie pedagoga [Personal potential and emotional burnout of the teacher]. CHelovek. Soobshchestvo. Upravlenie. № 3. S. 75-88 [in Russian].

3. Markov V.M. (2007) Mekhanizmy realizacii potenciala v kontekste akmeologii razvitiya [Mechanisms for realizing potential in the context of development acmeology]. Mir psihologii. № 2(50). S. 61-73 [in Russian].

4. Sytnik S.V. (2012) Osobystisnyi potentsial yak umova profesiinoi vzaiemodii [Personal potential as a condition of professional interaction]. Visnyk ONU imeni I.I. Mechnykova. Psykholohiia. T. 17. Vyp. 8(20). S. 168-175 [in Ukrainian].

5. Murashko I.V. (2010) Rozkryttia poniattia "osobystisnyi potentsial" ta yoho psykholohichnoi struktury [Disclosure of the concept of "personal potential" and its psychological structure]. Aktualni problemy psykholohii. Psykholohichna teoriia i tekhnolohiia navchannia. Kyiv : Smulson. T. 8. Vyp. 7. S. 196-205 [in Ukrainian].

6. Lushin P.V. (2017) Haos i neopredelennost': otstradaniya - $\mathrm{k}$ rostu i razvitiyu [Chaos and uncertainty: from suffering to growth and development]. K. : Astraya [in Ukrainian].

7. Maksymenko S.D. (2006) Heneza zdiisnennia osobystosti [The genesis of the implementation of personality]. K. : Vydavnytstvo TOV "KMM", 240 s. [in Ukrainian].

8. Maksymenko S.D. (2008) Zahalna psykholohiia [General Psychology] Vydannia 3-ye, pereroblene ta dopovnene : navchalnyi posibnyk. K. : Tsentr uchbovoi literatury, $272 \mathrm{~s}$. [in Ukrainian].

9. Popova N.V. (2009) Emocional'no-nravstvennyj potencial menedzhera kak klyuchevaya harakteristika professional'noj deyatel'nosti menedzhera. [Emotional and moral potential of a manager as a key characteristic of a manager's professional activity]. Nauchno-teoreticheskij zhurnal. Nauchnoe obespechenie sistemy povysheniya kvalifikacii kadrov. Vyp. 2. S. 77-83 [in Russian].

10. D.A. Leont'ev i dr. (2011) Lichnostnyj potencial: struktura i diagnostika [Personal potential: structure and diagnosis]. Moskva, Rossiya : Smysl [in Russian].

11. Manfred K.V. (2004) Mistika liderstva. Razvitie emocional'nogo intellekta [Leadership mysticism. Emotional intelligence development]. Per. s angl. M. : Al'pina Biznes Buks, 311 s. [in Russian].

12. Bogomolov A.M. (2008) Lichnostnyj adaptacionnaj potencial v kontekste sistemnogo analiza [Personal adaptive potential in the context of systems analysis]. Psihologicheskaya nauka i obrazovanie. № 1. S. 67-73 [in Russian]. 